\title{
Aile İçi Rollerde Babalığın Önemi
}

\author{
HATICE BALIN
}

Özet

İyi bir anne baba olmanın yolu sevgi, sabır, bilgi ve emekten geçmektedir. İdeal ebeveynin tanımı yoktur. Her ailede çocuk farklıdır. Dolayısıyla gereksinim ve iyinin tanımında da farklılıklar olur. Toplumların yapılarına ve kültürel kodlarına göre anne ve babalığın aile içi rolleri hakkında farklılıkların olduğu görülür. Bu değişkenlik çocuğun yetişmesindeki ebeveyn tutumlarına da yansır. Genel olarak, tüm toplumlarda çocuğun eğitiminde babalar çok uzun dönem unutulmuşlardır. Bu yüzden çocuğun eğitimi ile ilgili kuramlarda genellikle anneler ile ilgili çalışmalar daha fazlayken, babalar hakkında yapılan çalışmalar oldukça sınırlıdır. Aile içi ve kamusal alandaki rollerde, toplumsal değişimlerin yaşanmasıyla beraber babalığa dair çalışmalar belli bir oranda artsa dahi daha fazla çalışmaya gereksinim duyulmaktadır. Farklı toplumlarda özellikle de Türkiye'de aile içi çözülmelerin çoğunlukla annelerin çalışma hayatına katılması ve kamusal alandaki varlığının sonucunda ortaya çıktığı ileri sürülmektedir. Aile içi rol paylaşımında çocuğun fiziksel bakımı haricinde, eğitiminden de büyük ölçüde annenin sorumlu tutulduğu görülmektedir. Çalışmamızda çocuğa ilişkin rol ve sorumluluk paylaşımında babalık rolünün önemi ortaya koyulmaya çalışılmıştır. Bu çalışmada literatür taraması ile aile içinde babalığın rolü sorgulanmış, toplumsal cinsiyet bağlamında yer yer açımlanarak baba-çocuk ilişkisi düzeyinde babalık rolünün sosyolojik analizi yapılmıştır. Böylece tarihsel süreçte babalık rolünün şekillenişi, toplumsal cinsiyet tarafından belirlenimi ve bu rolün çocuğun gelişimindeki etkisini değerlendirmek amaçlanmıştır.

Anahtar Kelimeler: Babalık, Toplumsal Cinsiyet, Aile İçi Roller, Çocuk.

- ARASTIRMA MAKALESI-

Çocuk ve Medeniyet 


\begin{abstract}
The way to be a good parent is through love, patience, knowledge and effort. There is no definition of the ideal parent. In every family the child is different. Therefore, there are also differences in the definition of what is necessary and good. According to the structure and cultural codes of societies; One can also see that there are differences about the role of mother and father in the family. This diversity is also reflected in the attitude of the parents in raising the child. In general, in all societies, fathers are forgotten for a very long time in the upbringing of the child. Therefore, while there are studies on the mother in theories of child rearing, studies on the fathers are quite limited. Even though there are studies on fatherhood in family roles and roles in the public sphere, with the experience of social change more studies are needed. It is argued that in different societies, especially in Turkey, family dissolution mostly occurs as a result of mothers' participation in working life and their presence in the public sphere. In family role sharing, it is seen that the mother is largely responsible for the education of the child, as well as for the physical care of the child. In our study, the importance of the role of fatherhood in the sharing of roles and responsibilities regarding the child has been tried to be revealed. In this study, the role of fatherhood in the family was questioned by literature review, sociological analysis of the role of fatherhood at the level of father-child relationship was made by explaining in the context of gender. Thus, it is aimed to evaluate the shaping of the fatherhood role in the historical process, its determination by gender and the effect of this role on the development of the child.
\end{abstract}

Keywords: Fatherhood, Gender, Family Roles, Child.

\title{
Giriş
}

Ebeveyn olmak, kültürel ve toplumsal bağlamların içinde yer almaktadır (Kağıtçıbaşı,1998, s.56). Bir toplumsal bağlam içinde gerçekleşen annelik ve babalık, o toplumsal bağlam içinde belirlenen kadınlık ve erkeklik hakkında toplumun belirlediği şekiller içinde gerçekleşmektedir. Bu nedenle annelik ve babalık, bireysel bir deneyim olduğu kadar yaşanılan toplum ve kültürden de etkilenerek biçimlenmeye açıktır (Akçınar, 2017, s.16). Genelde annelik rolü konuşulur fakat son dönemlerde babalık rolü hakkında da konuşmak gerekmektedir. Ailede ev içi sorumluluğun yanında

Çocuk ve Medeniyet 2021/1 çocuğu büyütme sorumluluğu da anneye ait bir görev olarak algılanır. Babanın anne ve çocuk arasındaki ilişkiye dâhil olması, çocuğa alternatif bir ilişki biçimi sunmaktadır. Babanın bu 'araya girme' süreci çok değerlidir. Çünkü anneye kadın kimliğini hatırlatırken, çocuğa annesi dışında bir 
ötekinin de olduğunu göstermesi bakımından oldukça değerlidir (Atalar, $2017,58)$. Gelişimin çok hızlı olduğu ve çocukların bütünsel gelişimleri açısından oldukça önemli olan erken ve orta çocukluk dönemlerinde, ailenin ehemmiyeti birçok çalışma ve kuram tarafından desteklenmiştir. $\mathrm{Bu}$ kuramlardan biri olan, Bronfenbrenner'in Ekolojik Sistemler Kuramının, babalık ve ebeveynlik üzerine öne çıkan tartışmaların gelişiminde mühim bir katkısı bulunmaktadır (Bronfenbrenner,1979, s.35). Gelişim için temel olarak görülen ebeveynlik becerilerinin annenin yanı sıra babadan da beklenmesi, babalığın niteliğini zenginleștiren unsurlar arasındadır (Eslek, 2018, s.347). Bu sorumluluğun sadece anneye yüklenmesi sonucunda çocukların ergenlik döneminde cinsel kimlik hoşnutsuzluğu ve kimlik bunalımı gibi birtakım sorunlar yaşadığı gözlenmiştir. Problemlerin kaynağında ebeveyn tutumlarının olduğu görülmektedir. Babanın, büyüme sürecinde çocuğuyla nitelikli vakit geçirmediği ve anne ile bu sorumlulukta paydaş olmadığı yapılan literatür çalışmalarında tespit edilmiştir.

Toplumsal cinsiyet rolleri açısından bakıldığında, topluma ilintili olan, toplumun gelenek sistemi ile geçişkenlik gösteren bu yapı üzerinde geleneği artı ve eksisi ile yaşayan aileler bulunmaktadır (Bayhan, 2012, s.147). Geleneksel bağlamda aileye ve topluma etki eden bir diğer önemli nokta ise toplumsal ve aile içi cinsiyet rolleridir. Toplumsal cinsiyet biyolojik olarak cinsiyet ayrımını ifade eden kadınlık ve erkeklik yerine kadın ve erkek olma durumu ile alakalıdır. Kavram, toplumun ve kültürün erkek ya da kadın olmaya yüklediği anlamları ve beklentileri ifade eder. Toplumsal cinsiyet bağlamında aile içindeki bu geleneksel rol dağılımı babalık ve annelik kimliğinde de kendini göstermektedir. Şöyle ki baba aile içerisinde güç hiyerarşisinin tepesinde bulunmaktadır. Buna karşın anne, eşine tabi olmakla birlikte en önemli görevi çocuk yetiştirmek ve aileyi çekip çevirmek olan kişidir. Bu durumu J.J.Rousseau "Kadınlar annelik görevini iyi bir şekilde yerine getirdikleri takdirde erkekler de iyi bir koca ve baba olacak; çocukları ile arasında ise hakiki bir anne-çocuk ilişkisi oluşacaktır." (Rousseau,1966, s.24) cümlesiyle onaylamaktadır.

Böylesi bir ortam ailenin sağlıklı ve huzurlu bir şekilde sürekliliğini sağlarken, toplumun da geleceğine aynı şekilde etki edecektir. Mary Wollstonecraft yazmış olduğu eserlerde, özellikle yaptığı tartışmalarda, kadının erkeğin güdümünde bir varlık olarak yaratılmadığını, bilakis kadın ve erkeğin insan olarak eşit yaratıldığını vurgular. Wollstonecraft, "Kadın Haklarının Gerekçelendirilmesi” kitabının giriş kısmından başlayarak kitabın sonuna kadar Rousseau'ya hitaben yazar ve kitabında onun kadınlar ile ilgili düşüncelerine yer verir. Rousseau'nun düşüncesine göre, kadının hiçbir koşulda bağımsız hissetmesine izin verilmemesi 
gerektiği gibi kadının doğal kurnazlığını yönetebilmek için korkutulması ve erkeğin rahatlama konusundaki ihtiyacının giderilmesine her zaman cevap vermesi zorunluluğu vardır. Kısacası, Wollstonecraft Rousseau'nun kadını alımlı bir nesneye dönüşen köle olarak gördüğünden bahseder. Rousseau bu kadın tanımlamasında, doğaya dayanarak geliştirdiği iddianın savlarını daha da ileri götürerek, tüm erdemlerin temelini oluşturan doğruluk ve cesaretin yayılmasında belli sınırlar çizer. Çünkü Rousseau kadınlar için en büyük erdemin, erkeklere itaat eden bir nesne olmalarında yattığını vurgulamaktadır (Wollstonecraft, 2007, s.56). Aslında bu ve benzeri görüşleri sosyal bilimler literatüründe eleştirel bir bakışla ele alan ve tartışan Mary Wollstonecraft "Kadın Haklarının Gerekçelendirilmesi” kitabında Rousseau'nun "Emile” kitabındaki ideal kadın tipine dair düşüncelerine de cevap vermektedir. Vermiş olduğu cevapta Rousseau'nun kitapta bahsettiği, erkeğe boyun eğen, erkekleri memnun etmeye programlanmış süslü, narin, zayıf, güzel kadın tipine karşı; eğitimli, akıllı, düşünen ve muhakeme edebilen, ayakları üzerinde güçlü bir şekilde durabilen bir kadın profili çizmektedir. Muhakeme edemeyen bir insanın iffetli oluşunun hiçbir anlam taşımadığını ifade ederek, böyle bir insanın sadakatini hayvanın sadakatine benzetmektedir(Balin, 2019, s.7). Wollstonecraft ve Rousseau'nun bu karşıtlı̆̆ı kadın ve erkeğin toplumsal cinsiyet rolleri algısının boyutunu ortaya koymaktadır. Bu algının sonucunda aile içi rollerin nasıl etkilendiğini görmekteyiz. Babalık ile ilgili çalışmalarda da bu etki görülmektedir. Çalışmamızda babalığın toplumsal cinsiyet açısından aile içi rollerde incelenmesi ve babalık rolünün önemine değineceğiz. Öncesinde babalık rolünün tarihsel tanımı ve Türkiye'deki babalık anlayışından bahsedeceğiz.

\section{Babalık Rolüiün Tarihsel Tanımı}

Freud'un (1996) "Beş Konferans ve Psikanalize Toplu Bakış" ve Bowlby'in (1992) "The Origins of Attachment Theory"1 çalışmalarına bakıldığında anneliğin önemini anlatan görüşün daha yaygın olduğunu görülmektedir. Bu çalışmalarda annenin çocuk üzerindeki etkisinin babadan daha fazla olduğu, çocuğun kişilik gelişiminden sosyalleşmesine kadar annenin büyük ölçüde çocuğu şekillendirdiği vurgulanmaktadır. Babanın rolü ise anneyi destekleyen, ona yardımcı olan bir aktör olarak ortaya çıkar. Toplumsal yapının değişmesiyle kadın ve erkeğin rolleri arasında da belirgin değişimler yaşanmıştır. Geleneksel dönemde katı sınırlar ile ayrılan anne ve babalık, 
ev işi yapan ve çocuk bakımına dair sorumluluk alan baba figürü ile ilgili modeller görülmeye başlanmıştır. "Babalık tanımı ülkeden ülkeye, kültürden kültüre, hatta dönemden döneme değişebilmektedir. Ancak değişmeyen iki ortak özellik vardır: iyi bir baba olmak ve çocuğuna iyi bakabilmek." (Özkardeş, 2006, s.19-20).

Batı'da babalık rolü ile ilgili çalışmaların başlangıcına baktığımızda aile içi rollerdeki değişimin etkili olduğu görülmektedir. 1950'li yıllardan önce kadınların toplumsal olarak birincil rolleri, aileleri ile ilgili işleri olmuştur. Aynı zamanda kadınlar evlenene kadar bir işte çalışırken, evlendikten sonra ailelerine karşı sorumlulukları nedeniyle işlerinden ayrılmaları beklenmektedir. Ancak 1950'li ve 1960'lı yıllardan itibaren kadınların işgücüne katılım oranları giderek artmış; erkeklerin aile içindeki “tek başına ekmek parası kazanan” sosyal pozisyonları değişerek, ortak katılımla evin giderleri karşılanmaya başlamıştır (Cabrera ve ark.,2000; McDonough,Walters ve Strohschein,2002,s.23). Babaların çocuklarının yaşamlarına daha fazla katılım göstermelerine yönelik oluşan toplumsal bilinç, 1970'li yılların ortalarından 2000'li yıllara doğru olan süreçte şekillenmiştir (Finley ve Schwartz, 2004, s.29). Kwok ve Li'ye (2015) göre, babaların rolüne ilişkin bu toplumsal farkındalık sadece bireyci kültürlerde değil, toplulukçu kültürlerde de ön plana çıkmaya başlamıştır.

$\mathrm{Bu}$ artan toplumsal bilinç ile paralel olarak baba katılımı konusunda pek çok araştırma yürütülmüştür. Babalar ile ilgili çalışmalar 1980'li yıllardan önce başlamış fakat uluslararası düzeye taşınması 1990'lı yıllarda olmuştur. Babalığın rolüne dair yayınlar, dünyada ve ülkemizde bu yıllardan sonra çoğalmıştır. Baba katılımı hakkında yapılan araştırmalara baktığımızda ABD'de yapılan Kathleen Mullan Harris, Frank F. Furstenbeg ve Jeremy K.Marmer (1998) "Paternal İnvolvement With Adolescents in İntact Families: The İnfluence of Fathers Over The Life Course”2 adlı çalışma ön plana çıkmaktadır.

Harris, Furstenbeg ve Marmer yaptıkları araştırmada Ulusal Çocuklar Araştırması'ndan elde edilen boylamsal verileri kullanarak, bozulmamış ailelerde babaların ergen çocuklarla yeterli düzeyde vakit geçirmesinin niteliğini ve niceliğini ölçmüşlerdir. Babaların katılımındaki farklılıkları ailenin ve çocukların özelliklerine göre inceleyerek, babaların katılımının çocukların yetişkinliğe geçişi üzerindeki uzun vadeli etkilerini modellemişlerdir. Çalışma sonucunda ise babalar ergenlik dönemindeki çocuklarıyla ilgilenmediğinden, eşler arasında artan evlilik çatışması 
sonucunda boşanmalar meydana gelir. Araştırmacılar, babanın katılımının çocuklar için üç alanda faydalı etkileri olduğunu tespit etmiştir. Bu üç etkiden ilkinin eğitimsel ve ekonomik kazanım, diğerlerinin ise suçlu davranış ve psikolojik refah olduğu ortaya çıkmıştır. Ergenlik boyunca duygusal ilişkilerin seyrinin, suç davranışı ve psikolojik iyi oluş üzerinde de olumlu bir etkiye sahip olduğu yapılan araştırmalar sonucu ulaşılan bulgulardır.

İngiltere'de Elniri Flouri ve Ann Buchanan (2002) "Life Satisfaction in Teenage Boys: The Moderating Role of Father Involvement and Bullying" başlıklı çalışmalarında, okulda zorbalık ve düşük sosyal desteğin, çocuklarda nispeten zayıf ruh sağlığı ile ilişkili olduğunu öne sürmüşlerdir. İngiltere'de 13-19 yaşları arasındaki 1344 ergen erkekten elde edilen verilere dayanarak, araştırmalarda hafife alınan bir sosyal destek kaynağı olarak baba katılımının düşük yaşam doyumuna karşı bir koruma sağlayıp sağlamadığı araştırılmıştır. Bu çalışmanın sonucunda, çoklu regresyon analizi ile düşük baba katılımı ve akran mağduriyetinin, ergen erkek çocuklarda düşük yaşam doyumu düzeylerine önemli ölçüde ve bağımsız olarak katkıda bulunduğuna dair bulgular elde etmişlerdir. Ayrıca baba katılımının çocukları aşırı mağduriyetten koruduğuna ve tampon etkisi oluşturduğuna ilişkin kanıtlar da ortaya çıkmıştır.

Kanada'da Daniel Paquette, Christine Bolté, Geneviève Turcotte, Diane Dubeau ve Camil Bouchard (2000) "A New Typology of Fathering: Defining and Associated Variables"4 adlı çalışmalarında babaların öz bildirim ölçümlerine dayalı olarak ebeveynlikte babanın ailedeki rolü, katılımı ve ebeveyn tutumlarını araştırmışlardır. Mevcut araştırmada 468 ebeveyni incelemişlerdir. 0 ila 6 yaş arasında en az bir çocuğu olan, Fransa'da dezavantajlı bir ortamda yaşayan Kanadalı aileler ile derinlemesine mülakatlar yapılmıştır. Babalardan oluşan bir örneklem üzerinde yapılan bu araştırma sonucunda ise tanımlanan üç temel ebeveynlik türünün varlığı ortaya çıkmıştır. Otoriter, otoriter ve izin verici, yeni bir ebeveynlik türü olan uyarıcı ebeveynlik. Bu üçüncü gruptaki babalar psikolojik durumun kanıtladığı gibi daha fazla duygusal destek sağlayan babalar olarak görülmüştür. Ayrıca bu tür babaların çocuklarıyla ilgilendiğini ve onlarla daha sık etkinliklere katıldığını ortaya koymuşlardır. Bu babaların daha çok güvenli, sosyal ilişkileri olan babalar olduğu sonucuna varılmıştır. Ebeveynlikte stres düzeyini yoğun yaşayan otoriter ve disiplinli babaların fiziksel ceza uygulama riskinin yüksek olduğu sonucu çıkmıştır.

Çocuk ve Medeniyet 2021/1
3 Genç Erkeklerde Yaşam Doyumu: Baba Katılımının Yatıştırıcı Rolü ve Zorbalık

4 Yeni Bir Babalık Tipolojisi: Değişkenlerin Tanımlanması ve İlişkilendirilmesi 
Fransa'da ise Abigail Gregory ve Susan Milner'in "Fatherhood Regimes and Father Involvement in France and the UK"5 (2008) adlı çalışmasında iki ülke dikkate alınarak, babalık ve babaların çocuk bakımına ve ev işlerine katkısına ilişkin araştırma sonuçları karşıllaştırılır. Erkeklerin bu tür faaliyetlere katkısı hem Fransa'da hem de Birleşik Krallık'ta artıyor gibi görünse de değişimin yavaş olduğu ve baba katılımının, kadınların işgücüne katılım biçimleriyle veya kurumsal çerçeve tarafından sunulan destekle doğrudan ilişkili görünmediği ortaya konulmaktadır Yazarlar, bulgularını açıklamak için en uygun teoriyi araştırmakta ve öncelikle Pfau-Effinger'in toplumsal cinsiyeti teorileştirme bağlamında ortaya koyduğu çalışmalardan istifade etmektedirler. Yazarlar, baba katılımındaki değişim yavaş olsa da toplumsal cinsiyet düzenini değiştiren yasal ve örgütsel iş-yaşam dengesi önlemlerinin getirilmesinin, evdeki iş bölümünde pazarlıklı değişim için firsatlar yarattığı sonucuna varmışlardır.

Mathhijs Kalmijn (1999) "Father Involvement in Childrearing and the Perceived Stability of Marriage" 6 başlıklı Hollanda'da yürüttüğü çalışmasında, babaların çocuk yetiştirmeye yaptığı büyük yatırımların yüksek evlilik istikrarı ile ilişkili olduğu iddiasındaki ana hipotez, evlilik istikrarıyla ilgili iki rakip hipoteze karşı test edilmiştir. Hipotezler, Hollanda'daki hane halklarıyla ilgili ulusal bir anketten elde edilen veriler kullanılarak incelenmiştir. Yatırımlar, babaların çocuk yetiştirme görevlerine ne derece dâhil olduklarına ilişkin geriye dönük sorularla ölçülmüştür. Boşanma, karı kocaların evliliklerinin istikrarına ilişkin algıları hakkındaki sorularla dolaylı olarak ölçülmüştür. Çok değişkenli analizler, babaların çocuk yetiştirmeye daha fazla dâhil olduklarında daha istikrarlı bir evliliğe sahip olduklarını göstermektedir. Ancak eşlerin evlilik doyumunun yüksek olduğu durumlarda baba katılımının etkisi ortadan kalkmaktadır. İlgili babalar, olası bir ayrılıktan sonra kaybedecek çok yatırımları olduğu için değil, kocası çocuklarla güçlü bir şekilde ilgilendiğinde kadın daha mutlu olduğu için daha istikrarlı evliliklere sahiptir.

Babalık ile ilgili çalışmalar Batılı ülkelerle sınırlı değildir. Porto Riko'da Nacy Landale ve R.S. Oropesa'nın (2001) "Father Involvement in the Lives of Mainland Puerto Rican Children: Contributions of Nonresident, Cohabiting and Married Fathers" 7 isimli çalışması, baba katılımının doğasını ve belirleyicilerini incelemektedir. Porto Rikolu anneler ile görüşmeler

61

Çocuk ve Medeniyet 2021/1
5 Fransa ve Birleşik Krallık'ta Babalık Rejimleri ve Baba Katılımı

6 Çocuk Yetiştirmede Baba Katılımı ve Evlilikte Algılanan İstikrar

7 Anakara Porto Rikolu Çocukların Yaşamına Baba Katılımı: Katkıları Yerleşik olmayan, Birlikte Yaşayan Ve Evli Babalar 
yapılmıştır.Yapılan görüşmelerde çocukların fiziksel bakımında babaların annelere destek olup olmadığı araştırılırken, evli olmadan birlikte yaşayan babalar ve evli olan babalar arasında karşılaştırma yapılır. Araştırmada genel olarak ortaya çıkan sonuç kritik sorunun altını çizmektedir: Babaların Porto Rikolu çocuklara yaptığı katkılar nelerdir? Bu katkıların en önemlileri sosyoekonomik yeterliliğin olması ve çocuğun fiziksel bakımında babanın anneye yardımcı olmasıdır.

Diğer bir çalışma örneği ise Japonya'da yapılan Ishii-Kuntz, Makino, Kato ve Tsuchiya'nın (2004) "Japanese Fathers of Preschoolers and Their Involvement in Child Care" 8 adlı çalışmasıdır. Yapılan bu çalışmada göreceli kaynaklar, zaman mevcudiyeti, cinsiyet ideolojisi, yaşam düzenlemesi, çocuk bakımı talebi ve iş memnuniyeti faktörlerinin, genç Japon babaların okul öncesi çağdaki çocuklarının çocuk bakımına katılım düzeyleri ile nasıl bir ilişki içinde olduğu incelenmiştir. Bu faktörleri içeren teorik bir model, okul öncesi çocukları olan 442 Japon anne - baba çifttinden 1994 yılında toplanan veriler kullanılarak test edilmiştir. Babaların daha kısa çalışma saatleri, annelerin tam zamanlı çalışması, hanede daha az yetişkin ve daha fazla çocuk ve daha küçük yaştaki çocuklar bulunması gibi pratik düşüncelerin baba katılımının daha yüksek seviyeleri ile ilişkili olduğu bulunmuştur. Ulaşılan bulgular, Japon erkeklerinin çocuk bakım sorumluluklarını eşleriyle paylaşmalarını teşvik etme yönünde tartışılmıştır.

Bilim dünyasında, babaların çocuk gelişimindeki önemli rolünün anlaşılması ile aynı dönemde birçok ülkede aile içindeki rolleri etkileyecek mühim bir sosyal politika değişikliği gerçekleşmiştir. Çocuğun babasının soyadını alması dışında, sosyal politikalarda babalık rolüne fazla vurgu yapılmazken, 1980'li yıllardan sonra çocuğun dünyaya gelmesinin ardından yalnızca annelere verilen doğum izninin babalara da verilmesine yönelik yasal haklar getirilmiştir. Bu yasal değişiklik, politika yapıcılar tarafından babanın rolüne önem verilerek, babaların da çocuğun bakımında yer almalarının desteklenmesi, çocuğun yaşamında sadece annenin değil, babanın da önemli olduğunun üst kurumlar tarafından onaylandığını göstermesi açısından son derece önemlidir. Bu kapsamda ülkelerin uygulamalarına bakıldığında babalık izni, Fransa'da 1984 yılında getirilmiş; 2002 yılında izin süreci iki haftaya çıkartılmıştır (Gregory ve Milner, 2011). Benzer şekilde İngiltere'de de 2003 yılında yapılan yasal düzenlemeyle babalar için iki haftalık babalık izin süresi getirilmiştir (Lewis ve Campbell, 2007). Amerika Birleşik Devletleri'nde ücretli bir babalık izni politikası bulunmazken

8 Okul Öncesi Çocukların Japon Babaları ve Çocuk Bakımına Katılımları 
yetiştirilmesinde babaların da artık daha aktif rol almalarını desteklemek amacıyla baba eğitimi ve ekonomik yardımlar üzerinde durmaya başlamışlardır (Lawrence, Watson ve Stepteau-Watson, 2013). Sosyal reformlar açısından dünyada önde gelen İskandinav ülkelerine bakıldığında; genel olarak annelere verilen doğum izin süresi yüksek olmakla birlikte bu izin süresi istenirse babalar tarafindan da kullanılabilmektedir. Ancak babaların çocuğun bakımına katılımlarının arttırılması amacıyla bu izin süresi içinde babalar için ayrı bir kota belirlenmiştir. Bu kotanın süresi, İskandinav ülkeleri arasında iki hafta ile üç ay arasında değişmektedir (Datta-Gupta, Smith ve Verner, 2008). Ülkemizde de 657 sayılı Devlet Memurları Kanunu'nun 104. maddesinde 2011 yılında yapılan değişiklikle, "Memura, eşinin doğum yapması hâlinde, isteği üzerine on gün babalık izni verilir.” şeklinde düzenleme yapılmıştır (Resmî Gazete, 2011).

Babalık rolünün merkeze alındığı aile çalışmalarının öneminin vurgulanmasında ve sosyal politikalarda babanın rolüne ilişkin verilen yasal hakların oluşmasında kadının kamusal alanda çalışması belirleyici olmuştur. Toplumsal değişimin etkisine bağlı olarak;

1. Kadının özel alandan çıkarak tam gün kamusal alanda çalışmasıyla erkeklerin ev içi sorumlulukları paylaşma zorunluluğu ve çocukların bakımı ile yeni aile içi düzenlenmelerin yapıldığı,

2. Aile içi sorumluluğun çoğunlukla kadının üzerinde kalmaya devam ettiği,

3. Eğitim alanında yeterli düzeye ulaşamayan kadınların artık yüksek eğitim görerek iş bulabilir hale geldiği,

4. Çalışan ve ekonomik özgürlüğe kavuşan kadın sayısında artış olması ve buna bağlı olarak erkek rolünün etkilenmesi ve her iki cins arasında benzer şartların ortaya çıktığı savunulmuştur.

5. Ayrıca Batı'daki toplumlarda daha çok sayıda boşanmış ya da dul erkeğin tek başlarına çocuklarının bakım ve eğitim sorumluluğunu üstlenmeleri,

6. Geleneksel aile yapısının çekirdek aileye dönüşmesi, aile destek sistemlerinin zayıflaması ve çekirdek aile içindeki bireye düşen rol ve sorumlulukların değişmesi,

7. Küreselleşen dünyada göçün artması gibi durumlar da modern dönemde görülen değişimler arasında sıralanabilir.

Toplumda yaşanılan bu değişimler, aile içi rollerde değişkenliğe ve baba rolünün öneminin artmasına neden olmuştur. Babalığın tarihsel süreçteki 
tanımına baktığımızda, Batı'da bu tanım dört farklı aşamadan geçmiştir. (Özkardeş, 2006 s.27).

\section{Ahlâk öğretmeni babalar (18. yy.-19. yy.)}

18. ve 19. yüzyılın başlarına kadar babaların en önemli görevi çocuklarına ahlâk öğretmekti. Çocukların eğitiminden erkek çocukların meslek seçimlerine kadar bütün görevlerden baba sorumluydu. Annelerin bu sorumluluğu almamasının nedeni ise kadınların duygusal, naif olmaları ve güvenilir bulunmamalarıydı. Onlara göre kontrol edilemeyen kadınlar yoldan çıkabilirdi. Bu yüzden bu sorumluluğu baba üstlenmişti. İncil bu eğitimin kaynak kitabıydı. Yahudi ve Hıristiyan kutsal metinlerinde, ailedeki birlik ve otoritenin simgesi olan baba aynı zamanda çocuk için de en önemli rehber ve her durumda sığınılacak limandır. Babalık sıfatını aldıktan sonra hayatın yükünü ve sorumluluğunu daha fazla omuzlarında hissetmeye başlayan erkek, bu vakitten sonra evladının maddi ve manevi açıdan en güzel şekilde yetişmesinin birinci derecede sorumlusu haline gelmiştir. Çünkü artık o sıradan bir insan değil, çocuğu için rol modeldir. Ailesini her türlü tehdit ve tehlikeden korumak için var gücüyle mücadele edendir. Tabi bu esnada etrafa karşı her ne kadar gaddar ve zalim olsa ya da görünse dahi kendi evladına karşı merhametlidir (İpek, 2021). İslam dininde ise, çocuğun eğitiminde diğer dinlerde olduğu gibi öncelikli olarak baba sorumludur. $\mathrm{Hz}$. Muhammed çocuğunun eğitiminden sorumlu olan babalara şöyle tavsiyelerde bulunmuştur: "Bir baba çocuğuna güzel edepten (ahlâktan) daha iyi bir şey hediye etmez." Hadislerin bildirdiğine göre babaların çocuklarına hem kendileri hem çocuklar hem de toplum için gerekli olan güzel ahlâkı kazandırması istenmektedir. Hatta İbn Kayyim, "Çocukların çoğundaki bozukluğun sebebi babalardır. Onlar babalarının ihmali, dinin farz ve sünnetlerini öğretme işini terk etmeleri yüzünden bozulmuşlardır." demektedir. Üç semavi dinde de babanın ahlâk öğreticiliği tanımının var olduğu görülmektedir (Yılmaz, 2019, s.45).

\section{Evinin ekmeğini kazanan babalar (19. yy. başları - 20. yy. ortaları)}

19. yüzyılın başlarında endüstrileşmeyle birlikte babalar artık dışarıda çalışmaya başlar. Mesai saatlerinin uzun ve iş yerlerinin uzak olmasından dolayı annenin sorumlulukları artar. Çocukların eğitim ve ahlâki sorumluluğu da annelerin rolüne dâhil olur. Bu dönemde babaların çocuklar üzerindeki etkisi giderek azalır. Artık ahlâk öğretmeni babadan evine

Çocuk ve Medeniyet 2021/1 ekmeğini getiren babalar tanımlamasına doğru bir evrim olur. Bu dönemde annenin çocuk eğitimindeki rolünün artmasından dolayı erken çocukluk döneminde anne-çocuk ilişkisinin doğası ve önemi daha çok araştırmaya 
konu edilir. Freud'un (1996) psikonalitik kuramında anneliğe vurgusu ve Bowlby'in (1992) bağlanma kuramı bu konu hakkındaki araştırmaların temelini oluşturur.

\section{3. Çocuğun cinsel kimliğini kazanmasına yardımcı olan babalar (1940 ile 1965 yılları arası)}

1940-1965 yılları arasında dünya savaşlarının yoğun olduğu dönemde babaların savaşa gitmesi, savaştan dönmemesi babalık kavramına yeni bir tanım getirdi. Babaların yokluğundan dolayı kadınlar mecburi olarak çalışmaya başladılar ve kamusal alana dâhil oldular. Çalışan kadınlar artık erkeği yanında olmadan bağımsız olarak yaşamlarını sürdürmeyi öğrendiler. Çocukların babasız olarak büyümesi araştırmacıların çocuklar için babanın varlığının ne denli önemli olduğunu vurgulamalarına neden oldu. Ahlâk öğreten, ekmek parası kazanan babadan ziyade çocuğun cinsel kimlik kazanmasında etkin rol oynayan baba modelini öne çıkarmaya başladılar. Bu dönemde aile içi yaşanan değişimlerde anne-babanın yokluğu, her iki ebeveynin dışarıda olması farklı alışkanlıkları da beraberinde getirdi. Artık baba savaştan dönse bile dışarıda çalışan, evde emredici ve önemli kararları alan, örneğin taşınmaz mülklerin alımı-satımı gibi ya da siyaset ve politika konuşan tanımlamalarla var oldu. Ailede otoritenin ve disiplinin sağlanması yine babadan beklendi. Evine dönen anne ise ev içi sorumluluğunu yerine getirirken çocuğun bakımını da yüklendi. Ailede ara buluculuk görevi üstlenen duygusal destek verme annenin rolüne dâhildi. Bu dönemde, babalığın tanımında çocukların üzerinde doğrudan ama sınırlı bir yetkiye sahip bir anlayış hâkimdi.

\section{4. Çocuklarına bakan babalar (1965'ten günümüze)}

Annenin çalışma hayatına atılması, ailede babanın görev ve sorumluluklarında değişmelere neden olmuştur. Çocuğun bakımı ve büyütülmesine ilişkin sorumlulukların eşler arasında paylaşılması zorunluluğu ortaya çıkmaktadır. Bu gelişim ve değişmelere paralel olarak baba, ailenin gelirini sağlamanın yanı sıra, çocukların bakım ve eğitimlerinde önemli rol oynamaya başlamıştır. Annelerin mesaiye ya da nöbete kalması durumunda çocukları yataklarına götürme, yıkama, onlarla oynama gibi işleri babalar üstlenmiştir (Güngörmüş Özkardeş, 2012, s.23). Öte yandan anne ve baba aynı anda işten eve dönseler bile anne çoğunlukla evi toplayıp yemek hazırlama ile uğraşırken çocuk ile ilgilenmek babalara düşmektedir.

Çocuk ve Medeniyet 2021/1 Ancak toplumsal cinsiyet rollerinin oluşturduğu baskı, babanın bu yöndeki desteğinin istenilen düzeye ulaşmasını engellemektedir. Genel olarak baba -çocuk ilişkisinin değişmesi; ekonomik alandaki değişimlerin kadın- 
erkek rollerini etkilemesi, çalışan kadın sayısının artması, kadının tam gün dışarıda çalışmasına bağlı olarak erkeklerin evle ilgili sorumlulukları paylaşmaları zorunluluğunun oluşması çocukların bakımı ile ilgili yeni düzenlemelerin gerekliliği ve ev içi sorumlulukların çoğunlukla kadının üzerinde olması gibi nedenlerden kaynaklanmaktadır (Çağdaş, 2012, s.37).

\section{Türkiye'deki Babalık Anlayışı}

Türk toplumu değerlendirilirken babalık rolüne dair birçok özellik her ne kadar gündelik söylemde İslam'a atfedilse de çoğu, toplumsal cinsiyet etkisinde gelişmektedir. İslam kültürel değerlerine göre babalık rolünü $\mathrm{Hz}$. Muhammed'in aile içindeki tutum ve davranışlarında okuyabiliriz. Örnek göstermek gerekirse; babası Uhud savaşında şehit düşen Beşir’i mahzun görünce onu teselli etmiş ve "Ben senin baban olayım, Aişe annen olsun istemez misin?” diyerek küçük bir çocuğun gönlüne yenibaharlar getirmiştir (el-Askalânî,2011, s.258). Çocukları mutlu etmeyi kendine şiar edinen $\mathrm{Hz}$. Muhammed'in biricik kızı Hz. Fatıma ile olan ilişkisi bu bağlamda dikkate değer bir örnektir. Ebû Dâvûd es-Sicistânî’nin Es-Sünen”inde aktardığına göre Hz. Muhammed, kızı Fatıma yanına geldiğinde onu ayağa kalkarak karşılayan ve hatta kendi yerine buyur eden bir baba (Deyba, 2021, s.252) ve torunu ile oyunlar oynayan bir dededir. Uzun yıllar onun hizmetini gören ve yanında yetişip büyüyen $\mathrm{Hz}$. Enes, $\mathrm{Hz}$. Muhammed için şöyle demektedir: "Ailesine karşı Hz. Peygamber'den daha şefkatli hiç kimseyi görmedim." (Buhârî, 2010, s.315) Hadislerden de anlaşıldığına göre Hz. Muhammed baba olarak çocuklarına sevgi ve saygı göstermiş, ailesine şefkatle yaklaşarak çocuklarına karşı sorumluluğunu yerine getiren bir baba örnekliği sergilemiştir (el-Askalânî, 2011,s.235).

Batı'da ve İslam Medeniyetinde baba rollerine ilişkin örneklerin incelenmesinden sonra, Türkiye'deki örnekleri değerlendirebiliriz. Türkiye'deki baba modelinin değiştiği belirgin dönemler olmuştur. Tanzimat döneminde yaşanan birtakım değişikliklerle birlikte o dönemin aydınları, edebiyatçıları, sanatçıları eserlerinde maarif ve aile başlığını ele alırlar. Çünkü yaşanan bu köklü değişiklikleri toplumun kültürel, ekonomik, siyasi ve sosyal açıdan sağlıklı atlatabilmesi için insanları bilinçlendirmek ve farkındalık oluşturmak gerekiyordu. Güngörmüş Özkardeş ve Arkonaç (1998) Tanzimat Dönemi romanlarında baba temsilini incelemiştir. Ahmet Mithat (1844-1912) ve Namık Kemal (1840-1888) gibi dönem yazarlarının eserlerinden yola çıkarak, bu dönemde babanın anneden hem eğitim olarak hem de biyolojik olarak daha üstün olduğu ve çocuğun eğitimiyle babanın ilgilenmesi gerektiği görüşünün benimsendiğine dikkat çekmiştir. Bu 
yazarlara göre anne, çocuğun bilgiden ziyade şefkate ihtiyaç duyduğu ilk üç yılında önemlidir. Baba bu dönemde anneyi kontrol etmelidir. Çocuğun ve kadının eğitiminden sorumlu kişi olarak görülen Tanzimat dönemi baba rolü, "Ahlâk Öğretmeni Baba" olarak tanımlanabilir (Güngörmüş, 2012, s.45). O dönemin edebiyatçılarından olan Ahmet Mithat, eserlerinde çocuk eğitimi, çocuk eğitiminde anne-babanın görevleri, kadın eğitimi, sanat eğitimi, lisan eğitimi gibi konular hakkında müstakil eserler vererek halkı bilinçlendirme amacını yerine getirir. "Hikmet-i Peder" (1898), "Çocuk Melekât-ı Uzviye ve Ruhiyesi” (1899), “Ana Babanın Evlat Üzerindeki Hukuk ve Vezaifi” (1899), "Peder Olmak Sanatı" (1899) özellikle pedagojik açıdan kaleme alınmış eserler olup çocuk gelişimi ve aile eğitimi hakkında önemli bilgiler sunar (Mithat, 2013). Ahmet Mithat bu eserlerinde çocuğun eğitiminden babanın sorumlu olduğunu savunmakta ve babanın hem eğitimi hem de doğası açısından anneden üstün olduğunu anlatmaktadır. Mithat'a göre bu dönemde anne, çocuk için üç yaşa kadar önem ifade etmektedir. Yazılan eserlerde aile başlığı yer alırken bu eserler "Modern aile nasıl olmalı?" sorusuna cevap şeklinde yazılıyordu. Namık Kemal, Ahmet Mithat'ın aile ile ilgili eserlerindeki düşüncesine katılıyordu (Akt: Yıldız, 2000, s.12).

Namık Kemal (2005) bir bireyin eğitiminin ailede başladığına ve annebabanın çocuklukta aldığı eğitimin yetiştireceği çocukları etkilediğine inandığını belirtir. Bu konudaki fikirlerini ise "Aile" adlı yazısında açıkça ifade eder. Bireylerin çocukluk döneminde kötü bir eğitimden geçtikleri takdirde bunun ileride kuracakları aile hayatını da olumsuz etkilemesinin kaçınılmaz olduğunu söyler. Ayrıca Namık Kemal, anne-babanın çocuk eğitimindeki rolünün ne kadar önemli olduğunu da yazılarında vurgular (Akt: Yıldız, 2000, s.17, Kemal, 2005). Yine de ülkemizde o döneme ilişkin sosyolojik ve psikolojik alanda yapılmış çalışmaların az olması nedeniyle bu görüşlerin dönemin toplumsal özelliklerini bütüncül bir şekilde yansıttığını söylemek güçtür. Namık Kemal, Batı'daki ebeveynler gibi çocuğunun yetişmesinde sorumluluklarının bilincinde olan anne babaların çocuklarının da aile kavramının değerini anlayan, kişilik sahibi, iftihar edilecek bireyler olacağını vurgular. Ancak böyle bir düşünceye sahip olan ailelerin bahtiyar olabileceğini belirtir (Yıldız, 2000, s.19). Ayrıca Namık Kemal evlenip yuva kuran eşlerin anne baba olarak en önemli görevlerinin vatanına, milletine faydalı, hayırlı evlatlar yetiştirmek olduğunu, onları vatan için terbiye ve tahsil ettirmek gerektiğini sıklıkla hatırlatır. Babaların terbiye edemedikleri çocukların asırlar boyu kendilerini yetiştirmek için çalışsalar da hep bir yönden eksik kalacağını söyler (Yıldız, 2000, s.23).

Osmanlı'nın son dönemlerinde ailedeki değişim, kadın, çocuk eğitimi ve babanın rolü daha çok edebi eserlerde, köşe yazılarında, makalelerde yer 
almaktaydı. Türkiye Cumhuriyeti'nin tek partili dönemde aile politikalarına yönelik uygulamaları Medeni Kanun'un kabulü ile başlatılabilir. Yeni bir dünya tasavvuruna, hayat nizamına geçişi temsil eden bu düzenlemeler devrimin topluma intikalinin ve bütüncül bir değişimin başlangıç aşamalarını teşkil etmektedir. Bu noktada Cumhuriyet ideolojisinin, çağdaşlık ve Türklük söylemleri ile pekiştirdiği kadın ve gençlik politikaları üzerinden aile kurumuna yön verdiği görülmektedir. Dolayısıyla, Cumhuriyet devrimlerinin topluma kabul ettirilmesi süreci olarak görülebilecek Tek Parti Döneminde -özellikle 1940'lara kadar olan dönemaileye yönelik politikalar, bu süreci doğuran ideolojik kaygı çerçevesinde şekillenmiştir (Karagöz, 2015, s.3-10). Cumhuriyet'in ilk yıllarında sosyal yapı, Türk kültür ve aile yapısının geleneksel bir çizgide korunduğu yıllar olmuştur. Aile içi rollerde kadına, kurulan Cumhuriyet ideolojisine sahip çıkacak ve onu yaşatacak çocukların annesi rolü verilirken, baba için aile reisi rolü tanımlaması yapılmıştır (Akşit, 2012, s.157).

1950’li yıllar kırdan kente göçün yoğun yaşandığı bir dönemdir. Bu göç ile birlikte aile yapısında değişiklikler meydana gelmiştir. Bu değişikliklerinden biri geniş ailelerin çekirdek ailelere dönüşmesidir. Ailede yaşanan bir diğer değişiklik ise tarımla uğraşan aile üyelerinin kent yaşamında mesaili çalışma düzenine geçmesiyle bir arada olma zamanının kısalması olarak gösterilebilir. Bu nedenle aile içi iletişim ve bağlılık önceki dönemlere göre yoğun düzeyde değildir. Dolayısıyla baba-çocuk iletişimi ve birlikte geçirdikleri zaman azalmıştır. Bu yönde yapılan çalışmalar az olduğundan yeterli bilgiyi oluşturacak veriler bulunmamaktadır. Ülkemizde baba-çocuk ilişkisine dair yapılan çalışmalara baktığımızda (Özkardeş, 2006, s.30);

1) G. Özkardeş ve Arkonaç 1998 yılında ilkokul ve yüksekokul mezunu olan 80 baba ile nitel araştırma yöntemini kullanarak yüz yüze mülakatlar yapmıştır. Bu araştırmayı İstanbul'da gerçekleştirmişlerdir. Yapılan alan araştırmasındaki mülakat sorusunda kişilere,

a) Kendilerini nasıl bir baba olarak gördükleri,

b) İdeal bir babanın ve kendilerinden farklı bir babanın özelliklerini nasıl tanımladıkları sorulmuştur.

Araştırmanın sonuçlarına göre ilkokul mezunu olan babalar, kendileri ile ideal baba olma özellikleri arasında fark görmemiştir. Dikkat çeken bir başka nokta da babaların eğitim düzeyi arttıkça çocuklarıyla nitelikli vakit

Çocuk ve Medeniyet 2021/1 geçirmeye başlamaları ve çocuğu ile ilgili daha fazla sorumluluk almayı benimsediklerini belirtmeleridir. İlkokul mezunu babalar, çocuğa güven vermenin önemli olduğunu söylerken hoşgörülü davranmak gerektiğine 
de vurgu yapmışladır. Araştırmada tespit edilen en önemli bulgunun çocuğun yaşamında babanın daha aktif olması gerektiğidir. Babaların çeşitli yoğunluklardan çocukların hayatında yeterince aktif rol almadıkları yapılan araştırmanın sonuçları arasında yer almıştır (Özkardeş ve Arkonaç,1998).

2) Evans (1997) İstanbul ili içinde düşük sosyo-ekonomik düzeyden gelen, ilkokul mezunu kişilerin kendi babalık rollerine yönelik tutum ve katılımlarını incelemiştir. Araştırma 60 baba ile yüz yüze yapılan mülakatlar ile gerçekleştirilmiştir. Yapılan alan araştırmasında babaların kişisel anlatımları ve tutumları hakkında alınan bilgilerle babaların davranışları karşılaştırılmıştır.

Araştırmanın sonucunda babaların çocukların fiziksel bakımını genel olarak annelerin işi olarak gördüğü, kendilerinin üzerine düşen birinci dereceden sorumluluğun ise çocuğun maişetini kazanmak ve çocuğa zihinsel beceriler öğretmek, onun eğitimi ile ilgilenmek olduğunu belirtmişlerdir. Çocuğa toplumsal değerlerin öğretilmesini ise anne-babanın ortak sorumluluğu olarak görmektedirler. En önemli sorumluluk maddi açıdan çocuğa bakmak, sevgi ve şefkat göstermektir. En az önemli bulunan noktalar ise çocukla oynamak ve sıradan günlük ihtiyaçlarını gidermektir(Evans,1997, s.27).

3) Turan ve arkadaşları (2001) tarafından yapılan araştırma anne adayları ve eşleri ile gerçekleştirilmiştir. Bu araştırmada sosyo-ekonomik gelir seviyesi düşük olan kişiler tercih edilmiştir. Araştırma yüz yüze mülakat yöntemiyle yapılmıştır. Çalışmanın sonucuna göre ev ve çocukla ilgilenmek annenin sorumluluğundadır, babanın en önemli görevi ise ailenin maişetini sağlamaktır.

Genel olarak bahsettiğimiz bu çalışmalarda kültürel olarak yerleşik olan alışkanlıkların cinsiyet rollerine yansıdığı, eğitim seviyesinin yüksek olduğu ailelerde özellikle babanın eğitim düzeyi yüksek ise çocuklarına vakit ayıran, onlarla birlikte zaman geçiren ebeveynlerin olduğu, babaların birinci görevinin ise bilhassa aileyi geçindirmek olduğu sonuçlarına ulaşılmıştır. Toplumumuzda süreç içerisinde babalık rolünün ne tür değişimler geçirdiğini, nelerden etkilendiğini anlayabilmek için yapılan çalışmaların yeterli olmadığı aşikârdır. Bu yüzden babalık konusu ile ilgili daha fazla çalışmaya ihtiyaç duyulmaktadır. Türkiye'de yapılan babalık çalışmaları içerisinde AÇEV'in hazırladığı “Türkiye'de Babalığı Anlamak Serisi” önemli bir yer tutmaktadır. Bu seri üç rapordan oluşur. Güncel olarak hazırlanan araştırma raporu, Türkiye'de babaların ve babalığın durumunu ilk kez çok (Kocatepe ve Bilgi, 2018, s.45). 
AÇEV'in ilk raporunun araştırmasını yürüten Berna Akçınar ve ekibi (2017) “Türkiye'de Babalık ve İlgili Babalığın Belirleyicileri” adlı çalışmayı yapmıştır. Araştırmada, Türkiye'de Babalığı anlamak serisinin kapsamında babalığa yüklenilen anlamın ne olduğu, babalık uygulamalarının neler olduğu ve bu uygulamaların nasıl öğretildiğinin saptanması hedeflenmiştir. Alan araştırması 0-10 yaş arası çocuğa sahip 3000'den fazla babanın katılımıyla gerçekleşmiştir. Araştırma sonucuna göre babaların \%91'i, çocukların bakımından sorumlu birincil kişi olarak anneleri görmektedir. Katılımcıların geri kalan \% 0.9'u ilgili babalık davranışı sergiler. İlgili babalık davranışı sergileyen babaların \% 0.79'u ise çocukları ile yaptıkları ortak etkinlik olarak birlikte televizyon izleme eylemini sunmuştur. Türkiye'de aile içinde geleneksel rol dağılımının varlığına dikkat çeken ve kadına karşı cinsiyetçi tutumların "ilgili babalığın” önündeki en büyük engel olduğunun altını çizen araştırmanın bulgularına göre babaların önemli bir çoğunluğu (\%78) kadınların doğaları gereği erkeklerden daha güçsüz ve duygusal olduğunu söylemiştir. "Kadın gerektiğinde kocasına karşı sessiz kalmasını bilmelidir." diyen babaların oranı \%66 iken, "Erkek olmanın en önemli özelliklerinden biri gerektiğinde sözünü dinletebilmektir." şeklinde düşünenlerin oranı da \%65 ile yine oldukça yüksektir (Kocatepe ve Bilgi, 2018, s.44).

AÇEV'in hazırlamış olduğu ikinci çalışmasında Mehmet Bozok'un 2018 yılında yaptığı "Ebeveynlik, Erkeklik ve Çalışma Hayatı Arasında Türkiye'de Babalık" adlı araştırma raporu yer almıştır. Bu araştırma raporu yarı yapılandırılmış görüşmelere dayanmaktadır. Serinin ikinci çalışması olan rapor, Akçınar'ın hazırlamış olduğu rapordan esinlenmiştir. Bozok'un raporunda babalık kavramının toplumsal statüler ve roller üzerindeki etkisi incelenmiştir. Babalığa atfedilen rollerden biri, eve ekmek getiren babalık rolüdür. Bu tanım cinsiyetçi bir tutum içermektedir. Örneklem içerisinde sadece beşte biri erkek çocuklarının ev işlerinde yardımcı olmaları gerektiği görüşünü ortaya koymuşlardır.

AÇEV Serisinin üçüncü çalışmasında “Erkeklik ve Babalık Halleri” konulu araştırma raporu, Uğraş Ulaş Tol ve Demet Taşkan tarafından hazırlanmıştır. Çalışmada öncelikle dijital platformlarda babalık söylemleri araştırılmıştır. Yapılan bu araştırmada söylemler hiyerarşik ve ilerlemeci sıralamaya göre belirlenmiştir. "Çizgi dışı babalık" tanımlaması, yapılan serinin ilki olan "ilgili babalık "kavramının yerini almıştır. Çizgi dışı babalık tanımlamasında eşitlikçi, çocukları ile ilgilenen, onlarla yakın ilişkiler kuran, ev ve bakım işlerine paydaş olan baba ortaya koyulurken, hiyerarşinin en altında ise kapalı, otoriter ve çocuklarına mesafeli babaları tanımlayan "geleneksel babalık" yer almaktadır. Alan araştırması Ankara, İstanbul ve İzmir 
illerinde yaşayan kişilerle yapılmıştır. Görüşmeler 220 baba ve 50 kadın ile gerçekleşmiştir. Çalışmanın amacı, babalık algısının yukarıda belirtilen kategorilerden hangisine tekabül ettiğini bulmaktır. Araştırma sonuçlarına göre, "çizgi dışı babalık" kategorisinin toplumdaki karşılığı yok denecek kadar azdır $(\% 0,9)$. Babaların üçte birinden fazlası ise "geleneksel baba" özelliklerini sergilemektedir $(\% 35,5)$. Öte yandan, "geleneksel babalık" algısında süre giden bir "aşınma” vardır (Tol ve Taşkan, 2018, s.33).

Margaret Mead'e (1935) göre babalık rolü yaşadığı toplum ve kültürün etkisinde kalmaktadır. Kültürler arası babalık algısının farklılık gösterdiği, bazı kültürlerde babalığın disiplini sağlayan kişi olarak görüldüğü, bazı kültürlerde ise çocuklarıyla oyun oynayan kişi olarak da tanımlandığı bilinmektedir (Akt: Harkness ve Super, 1992, s.12). Babalık rolü ve babalık rolü algısının toplum ve kültür tarafından nasıl şekillendiği açıkça görülmektedir. Toplumsal algı ve kültürel algının şekillenmesinde en etkili yollardan biri olan eğitim, toplumun bu konudaki ihtiyacına cevap vermelidir (Şahin ve Mercan, 2017,s.14).

\section{Toplumsal Cinsiyet Açısından Babalık Rolii}

Toplumsal cinsiyet bir taraftan cinslere yönelik tutum, inanç ve kalıp yargılarla; diğer taraftan onun maddileşmesini sağlayan cinsiyete göre farklılaşan rol dağılımıyla varlığını devam ettirmektedir. Aile içi rol dağılımında bu anlayış görülür. Aile içi rol tanımlarının hepsinde toplumun bireylerden beklediği davranışlar vurgusu öne çıkarılmaktadır. Cinsiyetçi ideolojide kadınlık ve erkeklik, birbirinin zıttı ve birbirini dışlayan kategoriler olarak kurgulanır (Demren, 2007, s.40). Kadınlık evcimen, fedakâr, duygusal ve şefkatli olma gibi özellikler ile ilişkilendirilirken (Çetin, 2016, s.39), yine "kamusal alan" ile karşıtlık ilişkisi içinde tanımlanan "özel alan”, başka bir ifade ile ev, kadınlığın öncelikli mekânı olarak kabul edilir (Bora, 2014, s.37). Bu ikilikte, erkeklik, "kadınsı" olmayan, "kadın” olmayandır (Demren, 2007, s.34). Doğallığına ve gerekliliğine inanılan toplumsal cinsiyet, fırsat ve sonuçlarda kadın ve erkek arasındaki eşitsizliklerde kurucu rol oynar. Kadın ve erkeğin bir birey olarak yer aldıkları toplumdaki statülerini, rollerini, görev ve sorumluluklarını kapsar (Sancar, 2006). Sancar'ın bu yorumunu Robert Cornell da destekler; ona göre "Kadınlığı ve erkekliği kuran toplumsal ilişkiler cinsiyet rejiminin 2021/1 temelini oluşturur." (Connell, 1998, s. 23). İktidar ilişkilerine bağlı olarak toplumsal cinsiyet rollerine ilişkin erkek ve kadın olmalarına dair küçük yaşlardan itibaren bireylere birtakım şekiller sunulur. Örnek vermek gerekirse kız ve erkek çocukların küçük yaşta oynayacakları oyunlar ve 
giyimleri hatta meslekleri cinsiyetlerine göre ayrıştırılmaktadır. Çocuklar toplumsal ve kültürel baskının etkisine göre yetiştirilmektedir (Cengiz, 2004, s.25). Aksu Bora da toplumsal cinsiyetin sosyalleşme sürecinin bir sonucu olarak açıklanamayacağını, toplumsal cinsiyetin bir durum olmadığını, sürekli devam eden bir süreç olduğunu vurgulayarak tartışmaya dâhil olur. Bu süreçte bireylerin pasif olmadıklarını, aksine kendi “cinsiyetlen(diril)miş" öznelliklerinin inşa sürecinde aktif rol oynadıklarını da ileri sürer (Bora, 2014, s.22).

Bu tanımlamalar cinsiyetçi yargılar üretir. Baba güven duyulan, koruyup kollayan, keyifli vakit geçirilen, evi geçindiren biri olur. Baba, kamusal alanla ilişkilendirilmiş, parka gidilen, oyunlar oynanan, eğlenceli vakit geçirilen kişi olarak tarif edilmiştir. Kendi anneleri çoğunlukla anlayışsız ve kuralcı olarak tasvir edilirken baba hata yapmayan, yapsa bile mazur görülen yüce bir figürdür; evde yaşanan sorunlardan annelerini sorumlu tutmuşlardır. Toplumsal cinsiyet açısından kadın ve erkeğin tanımlaması öznelliği de ortaya koyar. Öznellik, cinsiyetlen(diril)miştir (Bora, 2014, s.35). Özne kavramı Foucault (2016) tarafından iki şekilde tanımlanmıştır: Birincisi "Denetim ve bağımlılık yoluyla başkasına tabi olan özne", ikincisi "vicdan ya da öz bilgi yoluyla kendi kimliğine bağlanmış olan özne”dir. Her iki tanım da Foucault'nun öznenin inşa ve nesneleştirilmesi sürecine ilişkin tartışmasında merkezi bir öneme sahip olan "iktidar" kavramsallaştırmasına dayanır. Foucault'a göre iktidar, bireyleri kategorilere ayırarak bireyselleştirir. Bireylere onların kendileri, birbirileri ve dünya ile kurdukları ilişkilerine şekil veren kimlikler sunarak günlük hayat pratiklerine doğrudan müdahale eder (Foucault, 2016, s.63). Foucault'ın öznellik ve kimlik tanımına Çağdaş Demren eserlerinde şu yorumu yapar; "Bu kimlik kategorileri ile şekillenen günlük yaşam deneyimlerinin öznesi olarak bireyler, bu kimlikleri icra ederler." (Demren, 2007; 2008, s. 92). Aile içerisinde oluşturulan bu hiyerarşik tanım ile kadının bu ilişkide öncelikli rolü "görünmez kılınan" ve kapitalist üretim ilişkilerinde "değer" karşılığı olmayan ev ve bakım işlerini yürütmektir. Kadının burada diğer ve en önemli rolü anneliktir. Çünkü annelik kadın rolünün ana bileşenini oluşturur. Anneliğe dair tüm tanımlar, cinsiyetçi rejimin düalist kalıplarından gücünü almaktadır. Bora ve Üstün (2005)'e göre, kadınlığa atfedilen duygusallık, ilgi ve bakım verici, evcimen, şefkatli ve fedakâr olmak gibi tüm bu özellikler kadının birincil rolleri arasındadır. Diğer en 2021/1 önemli vazifesi ise, dünyaya çocuk getirmek ve bakımını sağlamaktır (Bora ve Üstün, 2005, s.22). Bora ve Üstün'ün bu yorumuna ek olarak Bayraktar (2011) aile içi yaşanan her türlü problemin kadının annelik görevini ihmal etmesinin bir sonucu olduğunu belirtir. Ancak babanın evin dışında 
mücadele ederek para kazandığını vurgular ve bu sebepten dolayı evin içinde ailenin reisi ve karar alan konumunda olduğunu söyler.

Şahin ve Demiriz (2014) toplumsal cinsiyet bağlamında babalık tartışmalarına dair şu yorumu yapar: Ataerkil toplum yapısı, Türk erkeğinin geleneksel yetiştirilme tarzı ve babalık rolü algısını şekillendirir. Geleneksel cinsiyet kalıp yargılarının erkekleri evlerinin reisi, malların ve toplumsal yaşamın efendisi haline getirdiğini, bu durumun erkekleri, otoriter ve baskıcı kişiler haline dönüştürdüğünü savunurlar. Çocukla ilgili sorumluluklar, kadınlığa ve anneliğe atfedildiğinden, bir erkek tarafından bu rollerin benimsenmesi ve sürdürülmesinin erkeklik statüsünün kaybı şeklinde algılanabileceğini, böylece bu sorumlulukların babaların evden ve çocuk bakımından uzaklaşmasına sebep olduğunu belirtir. Babalık sadece biyolojik olarak baba olmaktan öte, toplumun babalığa yüklediği anlam ile şekillenmektedir (Şahin ve Mercan, 2017, s. 27). Cinsiyetçi tutumun yaşandığı aile içi rollerde son zamanlarda yaşanılan toplumsal değişim ile birlikte toplum ve aile yapısı, babalık rolü ve babalık rolü algısının değiştiği görülür. Babalık rolü geleneksel dönemde olduğundan daha modern ve karmaşık bir hale gelmektedir. Böylece, eskiden sadece çocuğun ve ailenin geçiminden sorumlu kılınan babalar, çocuğun hayatına daha fazla katılan, katılımcı ve aktif babalar haline gelmektedirler. Küresel bağlamda yaşanılan bu toplumsal değişimin, içinde yaşanılan toplumun, toplumsal değerlerin ve kültürel yapının aile yapısı üzerinde etkisi olduğu tespit edilirken, bu oluşan etkinin babalık rol algısını nasıl değiştirdiğini ve şekillendirdiğini de ortaya koymuştur (Mercan ve Şahin, 2017, s.33). Bu değişimler yaşansa dahi ailede baba rolünün istenilen düzeye ulaşması zaman alacaktır. Çünkü toplumsal cinsiyet rollerine dair kültürel kodların değişimi ancak kadınların toplumda ve ailede firsat eşitliğini yakalamasıyla olabilir. Hayatın her alanında özellikle aile içerisinde sorumlulukların adil paylaşılması, var olan yükü hafifletecek ve aile kurumunu sürdürülebilir kılacaktır.

\section{Çocuğun Gelişiminde Babanın Önemi}

Çocukların yetiştirilmesindeki sorumluluğun paylaşımı çok büyük önem arz eder. Özellikle, çocuğun büyüme dönemlerinde babanın paydaş olması, Mahler'e göre çocukta farklılaşmanın yolunu açar, onu bağımsızlaştırır ve ona yaratıcılık kazandırır (Mahler,1975, s.13). Bu durumda baba rolünün, bir çocuğun hayatındaki yerinin hem otoriteyle hem de dış dünya ile kurduğu ilişki biçimleriyle bağlantılı olacağını söylemek mümkündür (Atalar,2017, s.45). Bu iki ilişki biçimini biraz daha açarsak; çocukların, anneleriyle olduğu kadar babalarıyla da bağlılık ve güven ilişkisine, onların 
ilgi ve sevgisine ihtiyaçları vardır. Çocuğun, bilişsel, sosyal ve duygusal gelişiminde babanın rolü çok önemlidir. Baba çocuğuna karşı sıradan vakit geçiren bir ilişki içerisinde olmamalıdır. Çocuğuyla nitelikli vakit geçiren, ona rol model olan biri olmalıdır. Babanın çocuğuyla ilgilenmek için ayırdığı vakit onunla yaptığı etkinlikler çocuğa farklı tecrübeler kazandıracaktır. Ayrıca öğrenme ve zekâ gelişimini sağlayacaktır. Çocuğun özgüven gelişiminde babanın rolü çok önemlidir. Yapılan araştırmalarda babasız büyüyen çocukların okul hayatında başarılı olamadıkları ve sosyalleşemedikleri tespit edilmiştir. Çocukluk döneminde sürekli şiddete maruz kalan çocuklar ile babasız büyüyen çocukların aynı kaygıyı yaşadıkları gözlemlenmiştir (Kuzucu, 2011, s. 79-78).

Babanın çocuğun yetiştirilme sürecine aktif katılımı, yukarıda da belirttiğimiz gibi, çocuklarda ortaya çıkan davranış problemlerini azaltarak eşitlik ve adalet değerlerini içselleştirebilmelerine imkan tanır. "Ayrıca çocuğun doğumundan itibaren farklı ebeveyn tarzlarını görmesi, farklı tipteki insanlarla daha iyi ilişki kurmasına ve yeni koşullara daha kolay uyum sağlamasına yardımcı olmaktadır" (Ehrensaft, 1987, s.55).

Zeki Bayraktar'a göre çocuğun cinsel kimlik gelişiminde babanın rolü çok önemlidir. Erkek ve kız çocuğunun arasında farklılıklar olsa da sağlıklı cinsel gelişimde çocuklar anne ve babayı rol model alarak gelişir. Erkek çocuk küçük yaşlardan itibaren babayla kendini özdeşleştirerek onu taklit eder. Ergenlik döneminde bu süreç devam eder. Erkek çocukların zihninde erkeklik ile ilgili kavramların temeli oturur. Çünkü baba hayatlarında tanıdıkları ilk erkektir. Ailede babanın yokluğu çocuğun "özdeşleşme”" sürecini yaşayamamasına neden olur. Bu rol model ailede yoksa örnek alacağı dayı, amca, dede gibi yakın akrabanın olmaması da bu dönemde çocuğun cinsel kimlik gelişimi için büyük risk oluşturmaktadır. Kendisini annesiyle özdeşleştiren erkek çocuk, annesinin davranışlarını taklit eder, zaman zaman onun eşyalarını ve makyaj malzemelerini kullanır. Klinik ortamda annesi gibi olmak isteyen erkek çocuk vakalarına rastlanmaktadır. $\mathrm{Bu}$ örnekler her geçen gün artmaktadır. Buradan da anlaşılıyor ki erkek çocuk için baba ile özdeşleşmesi ileriki yıllar için de büyük önem arz etmektedir. Kız çocuklarının da karşı cins olarak muhatap oldukları ilk kişi babalarıdır. Kız çocuğun babası ile kurduğu ilişki gelecekte karşı cinsle kuracağı ilişkiyi inşa eder. Kısaca çocukların sağlıklı cinsel kimlik kazanımında başta baba olmak üzere annenin de etkisi çok önemlidir. 2021/1
Anne, çocuğun yetişmesinde merkezi rol oynarken, babanın rolü yapbozu tamamlayan en önemli parçalardan biridir. Çocuklara "Baba sizin için neyi ifade ediyor?" diye sorulduğunda erkek çocuklardan babanın dış dünyayı tanımayı, güçlü olabilmeyi, hayat şartlarındaki rekabeti, iktidarı, 
macerayı kısaca "erkek olmayı, erkek gibi davranmayı" temsil ettiğine yönelik cevaplar alınmıştır. Kız çocuklar ise baba ile kurdukları ilişkide diri ve sağlıklı olmayı, ayrıca özgüvenlerini pekiştirdiklerini belirtmişlerdir (Bayraktar, 2020, s.60).

Ayrıca baba, ailede "güven supabı" olarak değerlendirildiğinden, yokluğu durumunda çocukta bazı korkulara, güvensizlik belirtilerine ve sosyal gelişimde gecikmelere de rastlanabilir (Yavuzer, 2003, s.123). Ayşe Yalın (1979) "Baba ve Çocuk Etkileşimi” yazısında Spelke ve arkadaşlarının (1973) araştırmasından bahseder. Araştırmada özgüveni güçlüi olan çocukların, babalarıyla en çok ilişki kuran çocuklar oldukları tespit edilmiştir. Okulda yapılan bu çalışmada uyumsuz davranışlarıyla dikkat çeken 12 yaşındaki bir erkek çocuk, babasıyla olan iletişim kopukluğu ve yaşadığı olumsuzluğu şu cümlelerle dile getirmektedir: "Unutamadığım üzücü olay babamın, öğretmenlerimin her şikâyetinden sonra bana, 'Seni hastanelik edene kadar döverim.' diye tehdit etmesiydi. Keşke anne ve babam ayrı olsa; anne ve babası ayrı olan çocuklar daha rahatlar. Şu dünyaya, keşke... isimli arkadaşımın yerinde gelseydim. Onun annesi babası ona çok iyi davranıyor" (Yalın, 1979, s.24).

Örnekten de anlaşılacağı gibi baba ile iletişim kuramayan çocuğun bazı korku ve güvensizlikler yaşadığı ortaya çıkmaktadır. Baba rolünün sağlıklı ve güçlü ailenin oluşumundaki etkisinin ne kadar önemli olduğu araştırmalardan anlaşılmaktadır. Tabi burada anne ve babanın da iyi ilişkiler içerisinde olması gerekmektedir. Anne ve babanın arasındaki ilişki, anneçocuk arasındaki ilişkiyi de olumlu yönde etkileyebilmektedir. Babanın eşine verdiği destek, babanın varlığı, sevgi dilini kullanması ilişkilerde çözüm odaklı olması, anne-çocuk ilişkisinin daha sağlıklı olmasını sağlamaktadır. Bunun tam tersi olduğunda anne bu boşluğu doldurmak için ilgisini farklı şeylere yönlendirmektedir. Çocuğunu ihmal edebilir ya da çocuğuna odaklanarak ona karşı aşırı koruyucu bir tutum geliştirebilir. $\mathrm{Bu}$ da çocuğunun bağımsız kişilik gelişimini engellemesine neden olur. Annebabanın sağlıklı iletişim halinde olması bu açıdan çok önemlidir. Tutum, davranış ve söylemlerinde daha dikkatli ve farkındalık içinde olmaları gerekir. Onları her daim gözlemleyen çocukları olduklarını unutmamalıdırlar (Karaköse ve Karaköse, 2012, s.56). Genellikle çocukların babaları hakkında "Babam çok yoğun çalışıyor, onunla yeterince vakit geçiremiyoruz." gibi söylemleri çokça dile getirdikleri görülür. Ülkemizde babaların çok yoğun tempoda çalışmaları aile ve çocuklarına ayıracağı vaktin azalmasına neden olmakta ve çocuklarıyla ilgilenmelerini engellemektedir. Boş vakti olduğunda ise babalar bu imkânlarını farklı ailevi sorumluluklar veya kendi ilgi alanları doğrultusunda değerlendirmektedir. Aslına bakıldığında hangi 
statüde olursa olsun babaların da ailelerine ve kendilerine vakit ayıracağı bir mesai anlayışı gerekmektedir. Ülkemizde çalışan ebeveynler, mesai saatlerinin uzun olmasından dolayı yalnız çocuklarına değil kendilerine de vakit ayıramamaktadır. Bu tempoda çalışan annelerin ev-içi sorumlulukları iki katına çıkmaktadır. Bu koşullar içinde çocuk da baba ve annesinden kendisine zaman ayıramayacak kadar meşgul insanlar olarak bahsetmekte, onlarla olan iletişiminin giderek koptuğunu ifade etmektedir. Babalık modern dünyada babanın fiziksel varlığına indirgenmiş, temsil ettiği kuşatıcı rol oldukça zayıflamıştır. Önceki dönemlere kıyasla modern dönemde babaların çocuklarıyla nerdeyse yarı yarıya daha az vakit geçirdiklerini vurgulayan Kemal Sayar (2019)'a göre;

"Sanayileşme dönemi öncesinde babalar çocuklarıyla daha fazla vakit geçiriyor ve çocuklarına bağlllıklarını daha çok gösteriyor, hatta bunu çocukları erişkin olsalar bile devam ettiriyorlardl. Ama sanayileşme iki önemli değişimi de beraberinde getirdi; ailelerden ayrı çalışma alanları ve eşyanın değerindeki düşüş. Babalar çocuklarından ayrilırken, anneler de çocuklarının bakımın üstlenerek aileye destek oldular."

Değişen roller, anne babayı fonksiyonel açıdan birbirine yaklaştırmış, üstlenecekleri sorumluluklar noktasında iş birliğini gerekli kılmıştır (Akt: Yazıcı, 2019, s.23, Sayar, 2019). Sayar'ın da belirttiği gibi sağlıklı aile olmak için aile bireylerinin birbirlerine nitelikli vakit ayırması gerekmektedir. Özellikle aile içi sorumluluklar söz konusu olduğunda, ev ve çocuk ile ilgilenme anne ve baba arasında adil bir şekilde paylaşılmalıdır. Çocuklar aile içi sorumluluğun paylaşımını gördükçe ebeveynlerdeki bu dayanışma onlara özgüven sağlayacaktır. Sorumluluk alma konusunda çekingen ve tembel olmayacaklardır. Aile içi ekip çalışmasında çocuklar da kendi üzerlerine düşen sorumluğu yerine getirme bilincine sahip olacaktır.

\section{Sonuç}

Shalini Mitra'ya göre günümüzde babalar aile içi sorumluluğu paylaşmada daha duyarlı olmaya gayret ediyorlar. Çocukları için farklı bir baba modeli oluşturma çabası içindeler. Yaşadığımız toplumda nelerin önemli olduğunu fark edebilmek açısından babalığı yeniden tanımlamak mühimdir. Mitra, toplumsal cinsiyet rollerinin küçük yaşlarda kız çocuklarını bebeklerle annelik rolüne uygun hazırlarken, erkek çocuklarını ise şiddete yöneltici oyuncak, oyun ve silahlarla geleneksel erkek rolünü pekiştirerek 2021/1 büyüttüğünü belirtir. Bu hatalı bakış açısını değiştirecek kadar eleştirel düşünmenin de cesaret gerektirdiğini söyler. Erkek çocukların toplumsal cinsiyet rollerine göre yetiştirilmesine rağmen yapılan birçok araştırma sonucunda babalığın annelik gibi içsel olduğunu ortaya koymuştur. 
Araştırmanın diğer bir sonucunda ise babaların çocuğun neye ihtiyacı olduğunu hissetme ve anlama konusunda anneler kadar yetenekli olduklarını ifade eder (Mitra, 2003).

Babalığı yeniden tanımlamak ve bu farkındalığı arttırmak çocuklar ve yaşadığımız toplum için çok önemlidir. Bu yeteneğin ortaya çıkmasını sağlamak ve babaların farkındalığını arttırabilmek günümüz şartlarına uygun babalığın nasıl yapılacağı ile ilgili aile eğitim programlarına baba katılım oranlarının arttırılması ile mümkün olabilir. Toplumların kendi inanç ve değerlerine göre öğrenilen bir baba anlayışı olduğunu da görmezden gelemeyiz. Önemli olan, örnekliği olan bu değerlerin hakkıyla uygulanmasıdır. İslam dininin peygamberi $\mathrm{Hz}$. Muhammed'in örnekliği bu minvalde, Müslümanlara aile içi ilişkilerde nasıl bir tavır ve tutum sergilemesi gerektiği ile ilgili referans olmuştur. Kız çocuklarının diri diri gömüldüğü o dönemde kendisi kız çocuklarını bağrına basmıştır. Toplumu kuşatan ve batıl olan bu davranış ve tutumla inançla mücadele vermiştir. Ailede yaşanan tatsızlıkların tatlı dille, insanın gönlüne dokunarak çözüme ulaştırılması gerektiğini vurgulamış ve bunun örnekliğini birebir ailesi ile yaşamıştır. İslam dininin babalık statüsüne yüklediği sorumluluk peygamber $\mathrm{Hz}$. Muhammed örnekliğinde tanımlanırken, toplum yaşadığı değişimlere göre bu tanımlamayı yeniden yapmaktadır. Bu tanımlamalar ne olursa olsun değişmeyen tek bir tanımlama şudur ki babanın çocuğuna vereceği sevginin üstünde bir şey yoktur. Nakledilen hadislerden de görüldüğü üzere $\mathrm{Hz}$. Muhammed'in hayatı yalnızca babalık adına örnek teşkil etmediği gibi, aile içi rollerde toplumsal cinsiyet kavramını da ortadan kaldıracak örnekliği göstermektedir. Buhari kaynaklı hadiste; Esved İbni Yezid Hz. Ayşe’ye “ 'Hz. Muhammed evinde ne yapardı?' diye sordu. O da şu cevabı verdi: 'Ailesinin hizmetinde bulunurdu. Namaz vakti gelince de namaza giderdi."” (Kandemir, Çakan ve Küçük, 2017,s.289).

Bu çalışmamızda toplumsal cinsiyet bağlamında ailede babalık ve toplumsal statüsünün yanı sıra babalık rolünün ne kadar önemli olduğuna dair sahadan ve literatürden bulgular sunmaya çalışılmıştır. Sonuç olarak toplumda babalık rolünün farkındalığı arttırılarak, bunun bilincine varılmasının çocuğun hayatında ne kadar önemli bir yere sahip olduğu ile ilgili daha çok araştırmanın yapılması gerektiği anlaşılmaktadır. Bu konunun önemini Kemal Sayar (2019) şöyle ifade etmiştir:

“Erikson'un tanımladığı erişkinlik kutuplarından olan 'üretkenlik', kişinin çıkar beklentisi olmaksızın kendini yeni kuşakların geleceğine ve refahına adayabilme yetisi olarak açıklanmıştır. Üretken babalık yapanlar, çocuklarının bakımına, sosyal, duygusal, zihinsel ve fiziksel gelişimine önem verirler. Böyle bir babalık için ise iyi 
bir ahlâki gelişim ve tecrübe olması gerekir. Bu nedenle, babalı yapacak kişinin üretken babalı yapmasında kişinin nasıl bir aile yapısından geldiği, babasının aile içerisindeki rolü, annesinin iş ve eğitim hayatı, kendi hayatını ve benliğini nasıl anlamlandırdığı önemli etkenler olarak görülür. Erkeklerin çocuk yetiştirirken etkilendikleri faktörlerden biri de kendi babalarıdır. Ya kendi babalarmnn yaptıkların model alarak onlar da babalarn gibi davranacak ya da babalarma benzemek istemedikleri için babalarından farklı bir babalık sergileyeceklerdir."

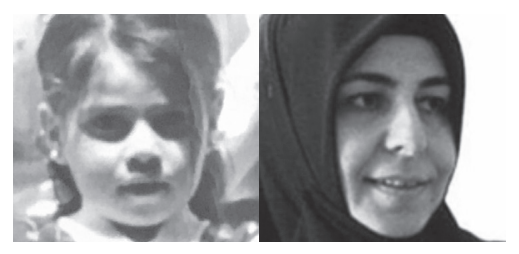

\section{Hatice Balin}

\section{Kaynakça}

Akçınar, Y. Y. (2017). Türkiye'de ilgili babalık ve belirleyicileri. AC̣EV. İstanbul: baskı Taymaz matbaacılık ve baskı çözümleri tic. Itd. ști.

Akșit, E. (2012). Kızların sessizliği. İstanbul: İletișim yayınları,sayfa:157.

Arkonaç, S. Ö. O. (1998). İki farklı eḡitim düzeyinde baba olma algısı. Marmara Üniversitesi Dergisi, İstanbul: https://dergipark.com. adresinde 2.07.2021 tarihinde erișildi.

Atalar, Z. T. (2017). Biraz da babalara yer açsak. Lacivert, Haziran sayı: 36, 54-58. 2 Temmuz 2021 tarihinde http://www.lacivertdergi.com/gundem/makaleler. adresinden erișildi.

Balin, Hatice. (2017). Toplumsal cinsiyet açısından kadının siyasal katılımı ve önündeki engeller, Yayınlanmamıs yüksek lisans tezi, Sabahattin Zaim Üniversitesi Sosyal Bilimler Enstitüsü sosyoloji Ana bilim dalı, İstanbul, 379-249.

Bayraktar, Z. (2020). Interseks-hermafrodit ve eșcinsel (norm ve norm dıșı cinsellik, farklar, nedenler, öneriler). İstanbul: Motto yayınları.

Bayraktar, S.(2011). Makbul anneler müstakbel vatandaşlar. Ankara: Ayizi yayıncılık.

Bayhan, V. (2012). “Beden sosyolojisi ve toplumsal cinsiyet”, Doḡu Batı Düșünce, (63), 147-164.

Bora, A. (2014). Kadınların sınıfı ücretli ev emeḡi ve kadın öznelliğinin inșası. İstanbul: İletișim yayınları.

Aksu, B. ve Üstün, İ. (2005). “Sıcak aile ortamı” Demokratikleșme sürecinde kadın ve erkekler. İstanbul: TESEV yayınları.

Bowlby j.ve Ainsworth M. Inge B., (1992). “The Origins Of Attachment Theory “Developmental Psychology", (28), 759-775.

Bozok, M. (2018). Ebeveynlik, erkeklik ve çalıșma hayatı arasında Türkiye'de babalık. İstanbul: AÇEV yayınları.

Bronfenbrenner, U. (1979). The Ecology Of Human Development. Cambridge, MA: Harvard University Press.

Buhari, İ. (2009). Sahih Buhari ve tercüme șerhi, İstanbul: Saḡlam yayınevi, 315.

Hatice Balin 
Cengiz, K., Uḡraș U.T. ve Önder K. (2004), “Hegemonik erkekliḡin peșinden.” Toplum ve Bilim, no. 101 S: $50-70$.

Connell, R. W. (1998). Kiși ve cinsel politika. toplumsal cinsiyet ve iktidar. (C. Soydemir, Cev.) İstanbul: Ayrıntı yayınları.

Cabrera, N. J., Tamis-LeMonda, C. S., Bradley, R.H.I, Hofferth, S. ve Lamb, M. E. (2000). Fatherhood in The Twenty-First Century. Child Development, 71, 127-136.

Cetin, Ö., Z., (2016). “Geleneksel Türk sinemasında erkeḡin deḡișen imgesi.” Erkek kimliḡinin deḡișemeyen halleri, (ed. Huriye Kuruoğlu), 121-143. Ankara: Nobel yașam.

Çaḡdaș, A., (2012). Anne-baba-çocuk iletișimi, (1. Baskı). Ankara: Eğiten kitap.

Deyba, I. (2021). Kütüb-i sitte muhtasarı, hadis kitabı 2. cilt. Ebu Davut Es-Sünen-i İstanbul: Polen yayınları, 252.

Demren, C.(2017). “Kahvehane erkekliḡi: Ankara'da bir gecekondu mahallesi örneḡi.” Doktora Tezi, Hacettepe Üniversitesi, 2007

Demren, C. (2008). "Kadınlık dolayımıyla erkeklik öznelliḡi." Cumhuriyet Üniversitesi Sosyal Bilimler,1(32), 73-92

Datta Gupta, N., Smith, N. ve Verner, M. (2008). Childcare and parental leave in the nordic countries: a model to aspire to?, Review Of Economics Of The Household, (6) 65-89.

Eslek, D. T. (2018). Ekolojik sistemler kuramı çerçevesinde göçmen. Dokuz Eylül Üniversitesi Sosyal Bilimler 3(20), 347-362. 23 Mayıs 2021 tarihinde https://dergipark. org.tr adresinden erișildi.

Ehrensaft, D. (1987). Parenting together men and women sharing the care of their children. Newyork: Free Press.

El-Askalânî, İ. H. (2011). El-Issabe Seçkin sahabeler. (çev. S. Erdoḡmuş). İstanbul: Saḡlam yayınevi, 288.

Evans, C. (1997). “Turkish fathers' attitudes to and Involuement in their fathering role: a low socio -economic sample”. (Türk Babalarının Babalık Rolüne Yönelik Tutumları Ve Katılımları: Düșük Sosyo-Ekonomik Bir Örneklem) B.Ü. Yayınlanmamıs yüksek lisans tezi.

Flouri, E. ve Buchanan, A. (2002). Life satisfaction in teenage boys: the moderating role of father involvement and bullying. aggressive behavior, 28, 126-133.

Freud, S. (1996). Beș Konferans ve psikanalize toplu bakıș, (çev. Kâmuran Șipal,). Cem Yayınevi, İstanbul.

Finley, G. E. ve Schwartz, S. J. (2004). The father involvement and nurturant fathering scales: retrospective measures for adolescent and adult children. educational and psychological measurement, 64, 143-164.

Foucault, M. (2016). Özne ve iktidar. İstanbul: Ayrıntı yayınları.

Gregory, A. ve Milner, S., (2008). Fatherhood Regimes And Father İnvolvement in France and the UK. Work \& Family, (11), 61-84.

Günay, G. ve Özgün B.(2011). Kadınların toplumsal cinsiyet rolleri çerçevesinde aile içi yașamı algılama Biçimleri." Türkiye Sosyal Araștırmalar,3 (15), 158-171.

Güngörmüs Ö.Oya (2012). Baba olmak (2. Baskı). İstanbul: Remzi Kitabevi.

Güngörmüș Ö., O. ve Arkonaç, S., (1998) “iki farklı eḡitim düzeyinde baba olma algısı”, M.Ü. Eğitim Bilimleri (10), 253-263.

Harris, K. M., Furstenbeg, F. F. ve Marmer, J. K. (1998). Paternal involvement with adolescents in intact families: The influence of fathers over the life course. Demography, 35, 201-216.

Harkness, S. S. (1992). The cultural foundations of father's role: evidence from kenya and the united states, father-childrelations; cultural and biosocial contexts. s. h. barry içinde, father child relatıons cultural and biosocial contexst, New York: Aldıne Gureyter, 192-200.

\section{Aile İçi Rollerde Babalığın Önemi}


Kaḡıtçıbașı, C..(1998).Kültürel psikoloji: kültür baḡlamında aile ve insan gelișimi, 1. baskı, İstanbul: Yapı Kredi Yayınları.

Karagöz, L. (2005). Türkiye'de aile politikalarında bütünlük intiyacı. İstanbul: İlmi Etüdler Derneḡi, 3-10

Karaköse, R.ve Karaköse, Ș. (2012). Cocuk eḡitiminde babanın etkisi. İstanbul: Yediveren yayınları, 36

Kemal, N. (2005); "Bizde ahlâkın hâli”, Osmanlı modernleșmesinin meseleleri bütün makaleleri 1, (Haz. Nergiz Yılmaz Aydoḡdu, İsmail Kara), Dergâh Yayınları, İstanbul, 488-491.

Kwok, S. Y. ve Li, B. K. (2015). A Mediation model of father involvement with preschool children in Hong Kong. Social Indicators Research, 122, 905-923.

Kocatepe, B. ve Bilgi, S. (2018). Toplumsal bir inșa olarak babalık: annelerin yașam öykülerinde baba imgesi Fe Dergi 10, no. 2, 43-59. 23.9.2021 tarihinde http://cins.ankara.edu.tr/ adresinden erișildi.

Kuntz,I., M., Makino, K., Kato, K. ve Tsuchiya, M. (2004). Japanese fathers of preschoolers and their involvement in child care. Journal of Marriage and Family, 66, 779-791.

Kuzucu, Y. (2011). Deḡișen babalık rolü ve çocuk gelișimine etkisi. Türk Psikolojik Danıșma Ve Rehberlik Dergisi, 4(35), 79-89.

Kalmijn, M. (1999). Father involvement in childrearing and the perceived stability of marriage. Journal Of Marriage And The Family, 61, 409-421.

Landale, N. S. ve Oropesa, R. S. (2001). Father involvement in the lives of mainland. social forces, 79, 945-968.

Lawrence, S. K., Watson, J., Stepteau-Watson, D. (2013). President obama and the fatherhood initiative. race, gender \& class, 20, 98-113.

Lewis, J. ve Campbell, M. (2007). UK Work/family balance policies and gender equality 1997- 2005. Social Politics, 14, 4-30.

Mahler, M. P. (1975). The Psyhologial Birth Of The Human Infant. New York: Basic Books.

Mitra, s. (2003). Bașarıı anne baba olmak. (N. Șekercioḡlu, Cev.) İstanbul: Platform yayınları.

Mithat, A. (2013/a); Ana-babanın evlat üzerindeki hukuk ve vezaifi, (Haz.:Gizem Akyol), İstanbul: Dergâh yayınları

(2013/b). Menfa -sürgün Hatıraları-, Kapı Yayınları, İstanbul 289

(2013/ C).Peder olmak sanatı, (Haz.:Gizem Akyol), Dergâh yayınları, İstanbul

McDonough, P., Walters, V. ve Strohschein, L. (2002). Chronic stress and the social patterning of women's health in canada. Social Science \& Medicine, 54, 767-782.

Nevevi, I. (1928). Riyazüs Salihin Hadisi șerif tercümesi, ( Kandemir, M.Y., Cakan, I.L., Küçük. R.(2017). Ravza yayınevi, İstanbul: 486

Nepomnyaschy, L. ve Donnelly, L. (2015). Father involvement and childhood injuries. journal of marriage and family, 77, 628-646.

Paquette, D., Bolt , C., Turcotte, G., Dubeau, D. ve Bouchard, C. (2000). A new typology of fathering: Defining and associated variables. Infant and Child Development, 9, 213-230.

Resmi Gazete (2011). Bazı alacakların yeniden yapılandırıması ile sosyal sigortalar ve genel sağlık sigortası kanunu ve diḡer bazı kanun ve kanun hükmünde kararnamelerde deḡișiklik yapılması hakkında kanun, 25 Șubat.

80

Çocuk ve

Medeniyet 2021/1
Rousseau, J. J. (1966). Emilie (6. Baskı), Cev. Hilmi Ziya Ülken vd. İstanbul: Türkiye yayınevi.

Sancar, S. S. (2006.). Bir de buradan bak: cinsiyet eșitsizliḡi bir "kadın” deḡil, toplumun sorunudur. Ankara: KA-DER yayınları.

Sayar, K. (2019). Baba olmak:12 Eylül 2021 https://kemalsayar.com/insana-dair/baba-olmak adresinden erișildi.

\section{Hatice Balin}


Șahin, H. V. (2014). Beș altı yașında çocuḡu olan babaların, babalık rolünü algılamaları ile Aile. Türkiye Sosyal Araștırmalar, 181(181), 273-294.

Sahin, F. ve Mercan, Z. (2017). Babalık rolü ve farklı kültürlerde babalık rolü algısı. (Hasan Kalyoncu Üniversitesi) Uluslararası Erken çocukluk eḡitimi çalıșmaları /International Journal of Early Childhood Education Studies, 2(2), 1-10.

Şahin, H. ve Demiriz, S. (2014). Beş altı yașında çocuğu olan babaların, babalık rolünü algılamaları ile aile katıım çalıșmalarını gerçekleștirmeleri arasındaki ilișkinin incelenmesi. Türkiye Sosyal Araștırmalar, 181(181), 273-294.

Turan, J.M., Nalbant, H., Bulut, A., Sahip, Y., (2001). “Including expectant fathers in antenatel education programmes in istanbul, Turkey" Reproducive Health Matters, (9) 18, Kasım.

Tol, U.,U.ve Tașkan, D.(2018). Erkeklik ve babalık halleri. İstanbul: AÇEV yayınları.

Ünüvar, Perihan (2008). Babaların 3-6 yaș grubu çocuklarıyla geçirdikleri zamanın niteliğini belirleme ve geliștirme. Doktora tezi, Selçuk Üniversitesi Sosyal Bilimler Enstitüsü, Konya, 32.

Wostonecraft, M. (2007). Kadın haklarının gerekçelendirilmesi.(D. Hakyemez, Cev.). İstanbul:Türkiye İs Bankası Kültür.

Yasin I., (2021).Yahudi ve Hristiyan kutsal metinlerinde çocuk algısı. Kayseri Üniversitesi Develi İslami Illimler Fakültesi Felsefe Ve Din Bilimleri Bölümü, (Bozok University Journal Of Faculty Of Theology), 19, 256.

Yalın, A. (1979). Baba ve cocuk etkileșimi. Psikoloji (5).

Yavuzer, H. (2003). Çocuḡu tanımak ve anlamak. İstanbul: Remzi.

Yazıcı, K. (2019). Diyanet aile ve diyanet haber: 13 Eylül 2021 tarihinde https://www.diyanethaber. com.tr/aile-dergisi/baba-olmak-h6143.html adresinden erișildi.

Yıldız, l. (2018). Tanzimat romanında eḡitim sorunu doktora Tezi Fırat Üniversitesi, Elâzığ.

Yılmaz, Y. (2019). İslâm'da aile ve çocuk eğitimi. h. p. içinde, II. Uluslararası Mevlidi Nebi Sempozyum Tebliğler Kitabı, 349. Sanlı Urfa: 22. 9.2021 tarihinde http://ilahiyat.harran.edu.tr/tr/ sempozyum/sempozyumlar/. Adresinden erișildi. 


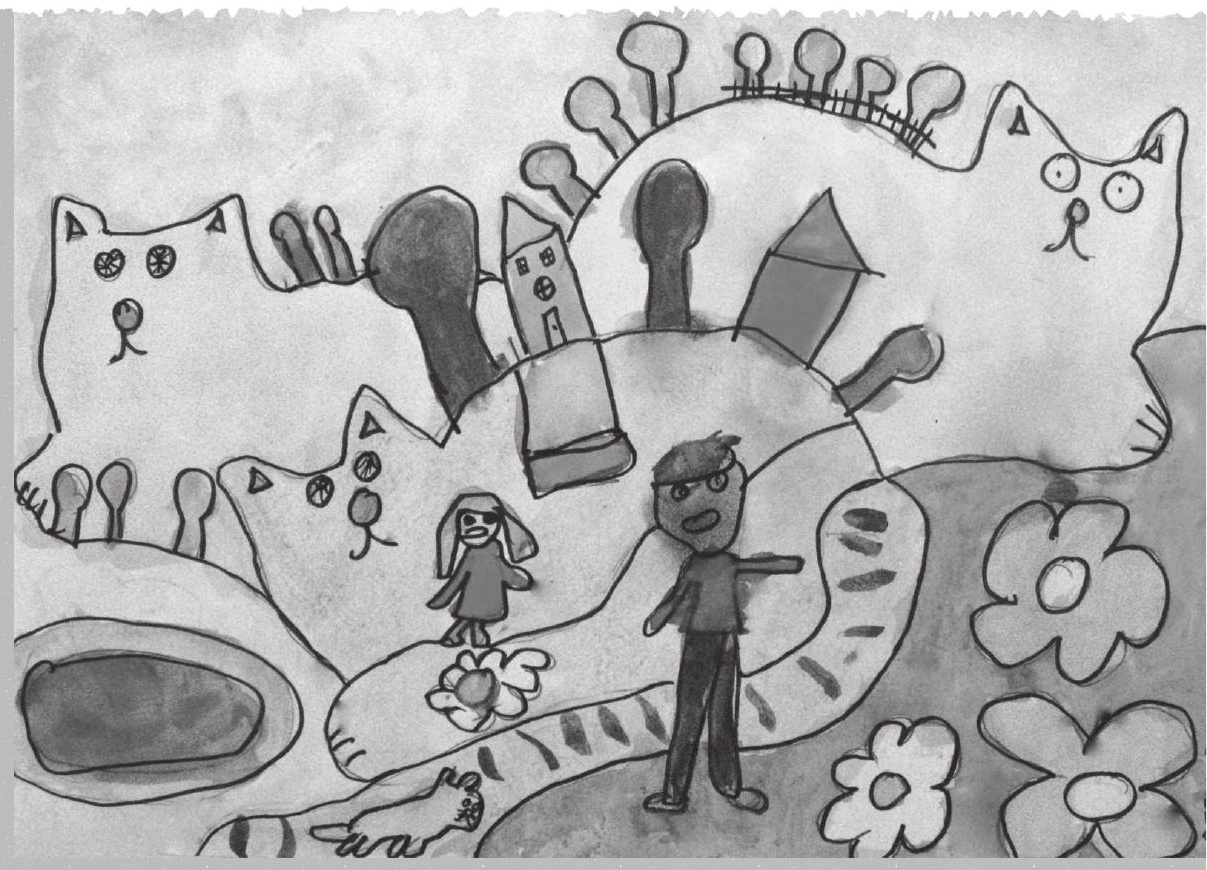

